\title{
Inhibition of in vitro macrophage-induced low density lipoprotein oxidation by thyroid compounds
}

\author{
L Oziol $^{1}$, P Faure ${ }^{1}$, N Bertrand ${ }^{1,2}$ and P Chomard $^{1,3}$ \\ ${ }^{1}$ Unité de Biochimie, Pharmacologie et Toxicologie, UFR des Sciences Pharmaceutiques et Biologiques, 7, Boulevard Jeanne d'Arc, BP 87900, 21079 Dijon \\ Cedex, France \\ ${ }^{2}$ Laboratoire de Pharmacologie et Toxicologie, Département Génie Biologique, IUT de Dijon, Boulevard Docteur Petitjean, BP 17867,21078 Dijon \\ Cedex, France \\ ${ }^{3}$ Laboratoire de Biochimie Médicale, Département Génie Biologique, IUT de Dijon, Boulevard Docteur Petitjean, BP 17867, 21078 Dijon Cedex, France \\ (Requests for offprints should be addressed to P Chomard, Unité de Biochimie, Pharmacologie et Toxicologie, UFR des Sciences Pharmaceutiques et \\ Biologiques, 7, Boulevard Jeanne d'Arc, BP 87900, 21079 Dijon Cedex, France; Email: pchomard@u-bourgogne.fr) \\ (L Oziol and $\mathrm{P}$ Faure contributed equally to this paper)
}

\begin{abstract}
Oxidized low density lipoproteins (LDL) are highly suspected of initiating the atherosclerosis process. Thyroid hormones and structural analogues have been reported to protect LDL from lipid peroxidation induced by $\mathrm{Cu}^{2+}$ or the free radical generator 2,2'-azobis-[2-amidinopropane] dihydrochloride in vitro. We have examined the effects of thyroid compounds on macrophage-induced LDL oxidation. Human monocyte-derived macrophages (differentiated U937 cells) were incubated for $24 \mathrm{~h}$ with LDL and different concentrations $(0-20 \mu \mathrm{M})$ of $3,5,3^{\prime}$-triiodo-L-thyronine $\left(\mathrm{T}_{3}\right), \quad 3,5,3^{\prime}, 5^{\prime}$-tetraiodo-L-thyronine $\left(\mathrm{T}_{4}\right), 3,3^{\prime}, 5^{\prime}$-tri-iodo-L-thyronine $\left(\mathrm{rT}_{3}\right)$, the $\mathrm{T}_{3}$ acetic derivative (3,5,3'-tri-iodothyroacetic acid; $\left.\mathrm{TA}_{3}\right)$ or L-thyronine $\left(\mathrm{T}_{0}\right)$ (experiment 1$)$. Cells were also preincubated for $24 \mathrm{~h}$ with 1 or $10 \mu \mathrm{M}$ of the compounds, washed twice, then incubated again for $24 \mathrm{~h}$ with LDL (experiment 2). Oxidation was evaluated by measurement of thiobarbituric acid-reactive substances (TBARS) and cell viability by lactate deshydrogenase release. In experiment

1, $\mathrm{T}_{0}$ had no effect, whereas the other compounds decreased LDL TBARS production, but $\mathrm{T}_{3}$ and $\mathrm{TA}_{3}$ were less active than $\mathrm{T}_{4}$ and $\mathrm{rT}_{3}\left(\mathrm{IC}_{50}: 11 \cdot 0 \pm 2 \cdot 6\right.$ and $8 \cdot 1 \pm 0 \cdot 8$ vs $1.4 \pm 0.5$ and $0.9 \pm 0.3 \mu \mathrm{M}$ respectively). In experiment 2 , the compounds at $1 \mu \mathrm{M}$ had no effect; at $10 \mu \mathrm{M}$, $\mathrm{T}_{3}$ and $\mathrm{rT}_{3}$ slightly reduced LDL TBARS production, whereas $\mathrm{TA}_{3}$ and $\mathrm{T}_{4}$ inhibited it by about $50 \%$ and $70 \%$ respectively. TBARS released by the cells were also highly decreased by $T_{3}, T_{4}, r T_{3}$ and $\mathrm{TA}_{3}$ in experiment 1 , but only by $\mathrm{T}_{3}(30 \%)$ and $\mathrm{T}_{4}(70 \%)$ in experiment 2 . Cell viability was not affected by the compounds except slightly by $\mathrm{TA}_{3}$ at $10 \mu \mathrm{M}$. The data suggested that the physicochemical antioxidant capacity of thyroid compounds was modulated by their action on the intracellular redox systems of macrophage. Overall cellular effects of $\mathrm{T}_{3}$ led to a reduction of its antioxidant capacity whereas those of $T_{4}$ increased it. Thus $\mathrm{T}_{4}$ might protect $\mathrm{LDL}$ against cellular oxidation in vivo more than $\mathrm{T}_{3}$.

Journal of Endocrinology (2003) 177, 137-146
\end{abstract}

\section{Introduction}

Many data support the idea that oxidative modifications of low density lipoproteins (LDL) contribute to enhance their atherogenicity (Chisolm \& Steinberg 2000, Witztum \& Steinberg 2001). Oxidized LDL can attract monocytes that adhere to the intravascular endothelium and migrate to the subendothelial space where they differentiate into macrophages. Scavenger receptors of macrophages, that are not downregulated by cellular cholesterol content, capture oxidized LDL whose lipids accumulate into the cells. Thus cholesterol-loaded macrophages change into foam cells that invade the arterial wall inducing the fatty streak, an early step in atheromatous plaque formation (Kaplan \& Aviram 1999).
Among factors responsible for LDL oxidation in vivo, monocyte-derived macrophages themselves are likely candidates, particularly at the beginning of vascular lesions. Indeed, they are prominent in arterial lesions and are able to generate reactive oxygen species (ROS) after activation of enzymes such as 15-lipoxygenase, myeloperoxidase or NADPH oxidase (Chisolm et al. 1999, Kaplan \& Aviram 1999). Transition metal ions such as copper and iron, which are present in atherosclerotic plaques, may also contribute to LDL oxidation (Lamb et al. 1995). For example, ferrous ions $\left(\mathrm{Fe}^{2+}\right)$ induce lipid peroxidation of cultured macrophages, increasing their ability to oxidatively modify LDL (Fuhrman et al. 1994).

Hypothyroidism is associated with cardiovascular diseases due to increased plasma total and LDL cholesterol 
contents which are normalized by thyroid hormone treatment (O’Brien et al. 1997, Martinez Triguero et al. 1998). This is also true in patients with mild thyroid failure, i.e. in subclinical hypothyroidism (Danese et al. 2000). Oxidizability of LDL was reported to be increased in hypothyroid patients (Sundaram et al. 1997, Costantini et al. 1998), increasing the atherogenic risk, but normalized by a $3,5,3^{\prime}, 5^{\prime}$-tetraiodo-L-thyronine $\left(\mathrm{T}_{4}\right)$ treatment (Diekman et al. 1998). Thus thyroid hormones, which are suspected to increase oxidative stress during hyperthyroidism (Bianchi et al. 1999), may also have antiatherogenic properties when they are used in the treatment of hypothyroid states.

Thyroid hormones and structural analogues have been shown to decrease the in vitro LDL oxidation induced by cuprous ions $\left(\mathrm{Cu}^{2+}\right)$ (Hanna et al. 1993, Chomard et al. 1998), the free radical generator 2,2'-azobis-[2amidinopropane] dihydrochloride (AAPH) (Oziol et al. 2001) or human endothelial cells (Hanna et al. 1995). However, their effect on macrophage-induced LDL oxidation is unknown. In the present study, we measured LDL oxidation induced by cultured human monocytederived macrophages preincubated or not with different thyroid compounds: $\mathrm{T}_{4}$ and 3,5,3'-tri-iodo-L-thyronine $\left(\mathrm{T}_{3}\right)$, the thyromimetic-active thyroid hormones; $3,3^{\prime}, 5^{\prime}$ tri-iodo-L-thyronine (reverse $\mathrm{T}_{3}, \mathrm{rT}_{3}$ ), the thyromimeticinactive hormone; 3,5,3'-tri-iodothyroacetic acid $\left(\mathrm{TA}_{3}\right)$, the acetic catabolite of $\mathrm{T}_{3}$; and L-thyronine $\left(\mathrm{T}_{0}\right)$, the hormone structure-like compound without iodine. Macrophage oxidation and viability were also appreciated.

\section{Materials and Methods}

\section{Materials}

Thyroid hormones and their analogues, 2-thiobarbituric acid, trichloracetic acid, 1,1,3,3-tetramethoxypropane, phorbol 12-myristate 13-acetate (PMA) and $\mathrm{FeSO}_{4}$ were purchased from Sigma (Saint-Quentin, France). RPMI1640 medium, phosphate-buffered saline (PBS), antibiotic and antimycotic solution and fetal calf serum were provided by Life Technologies (Cergy Pontoise, France), whereas Ham's F-10 medium was from Polylabo (Strasbourg, France).

\section{Macrophage-induced LDL oxidation experiments}

LDL preparation Human plasma was withdrawn in the presence of citrate-phosphate-dextran from healthy volunteers selected by the Blood French Establishment of Burgundy, France. The plasma was supplemented with $1 \mathrm{~g} / 1$ EDTA- $\mathrm{Na}_{2}$ and LDL (density=1.019-1.063) were immediately isolated by density-gradient ultracentrifugation for $15 \mathrm{~h}$ at $375000 \mathrm{~g}$ and $15{ }^{\circ} \mathrm{C}$ (Kleinveld et al. 1992) using a Centrikon T-1190 centrifuge (Kontron
Instruments, Milan, Italy). The purity of LDL was evaluated by $0.5 \%$ agarose gel electrophoresis (Paragon Lipogel kit; Beckman, Fullerton, CA, USA). Fresh LDL were kept under argon and in darkness at $4{ }^{\circ} \mathrm{C}$ for up to 15 days. Before use, LDL-containing fractions were dialyzed in darkness for $24 \mathrm{~h}$ at $4{ }^{\circ} \mathrm{C}$ against $0 \cdot 01 \mathrm{M}$ phosphate buffer, $\mathrm{pH} 7 \cdot 4$, containing $0 \cdot 15 \mathrm{M} \mathrm{NaCl}, 0 \cdot 01 \%$ EDTA and $1 \%$ chloramphenicol. The buffer was first made oxygen-free by passage through a Millipore filter $(0.45 \mu \mathrm{m}$; SaintQuentin, France) followed by purging with nitrogen for $30 \mathrm{~min}$. The protein concentration of dialyzed LDL was measured by the Lowry method modified by Markwell et al. (1978).

Compound preparations Thyroid hormones and their analogues were dissolved in $50 \mu \mathrm{l} 0.5 \mathrm{M} \mathrm{NaOH}$ which were quickly completed to $10 \mathrm{ml}$ with extra-pure water. The $1 \mathrm{mM}$ solutions obtained were kept for up to 5 days at $4{ }^{\circ} \mathrm{C}$ before their further extemporaneous dissolution in extra-pure water. The working solutions obtained ranged from 25 to $1000 \mu \mathrm{M}$.

\section{Monocyte culture and monocyte differentiation into} macrophage Monocytic U937 cells were cultured in RPMI-1640 medium containing 10\% heat-inactivated fetal calf serum, $100 \mathrm{U} / \mathrm{ml}$ penicillin, $100 \mu \mathrm{g} / \mathrm{ml}$ streptomycin and $0.25 \mu \mathrm{g} / \mathrm{ml}$ amphotericin B. The cells were fed every 3 days and cultivated at $37^{\circ} \mathrm{C}$ in a humidified atmosphere of $5 \% \mathrm{CO}_{2}$ and $95 \%$ air. To ensure exponential growth, cells were resuspended at a density of $0.5 \times 10^{6}$ cells $/ \mathrm{ml}$ in fresh complete medium $24 \mathrm{~h}$ before differentiation. Macrophagic differentiation and activation were obtained in six-well culture plates $(2.5 \mathrm{ml} /$ well $)$ following $48 \mathrm{~h}$ incubation of $0.45 \times 10^{6}$ cells $/ \mathrm{ml}$ with $100 \mathrm{nM}$ PMA in complete medium. The cells were differentiated into 80-90\% adherent monocyte-derived macrophages, hereafter denoted as macrophages.

Oxidation of LDL by macrophages incubated with thyroid compounds The non-adherent undifferentiated cells, traces of RPMI-1640 medium or fetal calf serum were removed from wells by two 5-min PBS washes. The following were successively added to the wells: $20 \mu \mathrm{l}$ thyroid compound working solution, $20 \mu \mathrm{l} 250 \mu \mathrm{M} \mathrm{FeSO}_{4}$ and 10-20 $\mu$ l dialyzed LDL in order to obtain a final concentration of $100 \mu \mathrm{g}$ protein $/ \mathrm{ml}$, and total volume was completed to $1 \mathrm{ml}$ with serum-free Ham's F-10 medium without phenol red. The cells were then incubated for $24 \mathrm{~h}$ at $37^{\circ} \mathrm{C}$ under $5 \% \mathrm{CO}_{2}$ as usual.

No phenol red was added in order to avoid optical interferences with the pink chromophore measured at the time of assay of thiobarbituric acid-reactive substances (TBARS, see below). Note that Ham's F-10 medium contained $3 \mu \mathrm{M} \mathrm{Fe}{ }^{2+}$ leading to an $\mathrm{Fe}^{2+}$ final concentration of $8 \mu \mathrm{M}$. The small volume of added ferrous ions 
did not alter the $\mathrm{pH}$ of the cell medium. Thyroid compound final concentrations ranged from 0.5 to $20 \mu \mathrm{M}$, corresponding to $0 \cdot 0025$ to $0 \cdot 1 \%$ of diluent $\mathrm{NaOH}$.

Several controls were made simultaneously under the same conditions, removing one of the medium components but maintaining the volume of its diluent. Controls without LDL were performed in order to estimate cellular membrane peroxidation. Three wells of each six-well culture plate were used for these controls, whereas the other three wells were used for one tested thyroid compound, i.e. each assay was performed in triplicate. Controls without thyroid compound were made to appreciate a possible effect of the different $\mathrm{NaOH}$ concentrations on the cells. Finally, controls without cells allowed the estimation of spontaneous LDL oxidation.

\section{Oxidation of LDL by macrophages preincubated} with thyroid compounds After the differentiation and the PBS washes described above, cells were preincubated for $24 \mathrm{~h}$ as usual in phenol red-free Ham's F-10 in the presence of two concentrations of thyroid compounds (1 or $10 \mu \mathrm{M})$. Then, after two PBS washes, cells were incubated again for $24 \mathrm{~h}$ with $\mathrm{FeSO}_{4}$ and LDL at the same concentration as previously. Macrophages in these conditions are henceforward denoted as preincubated cells.

In order to control the first incubation, cells were simultaneously incubated for $24 \mathrm{~h}$ in phenol red-free Ham's F-10 alone, and then $24 \mathrm{~h}$ again with $\mathrm{FeSO}_{4}$, LDL and a thyroid compound. In each case, controls similar to the ones above were performed, except for the controls without cells since spontaneous LDL oxidation was found to be negligible (Fig. 1). Macrophages in these conditions are henceforward denoted as non-preincubated cells.

Measurement of lipid peroxidation Lipid peroxidation was estimated by TBARS measurement, using freshly prepared TBARS reagent made of trichloracetic/ thiobarbituric/chlorhydric acids $(13 \cdot 6 / 0 \cdot 36 / 2 \cdot 4 \%, w / v)$. At the end of each experiment, cell supernatants were removed and lipid peroxidation was stopped by the addition of $50 \mu \mathrm{l}$ EDTA $(1 \mathrm{mM}$ final) and $50 \mu \mathrm{l}$ butylhydroxy-toluene $(0 \cdot 2 \mathrm{mM}$ final $)$ at $4{ }^{\circ} \mathrm{C}$. The mixture was then centrifuged $5 \mathrm{~min}$ at $207 \mathrm{~g}$ to remove any detached cells. The supernatant $(550 \mu \mathrm{l})$ and the TBARS reagent $(1 \mathrm{ml})$ were placed in Pyrex centrifuge tubes with a screw cap, and the closed tubes were mixed and heated at $100{ }^{\circ} \mathrm{C}$ for $15 \mathrm{~min}$. The tubes were then cooled and centrifuged at $1300 \mathrm{~g}$ for $15 \mathrm{~min}$, and the absorbance of the supernatant was measured at $532 \mathrm{~nm}$. Quantification of TBARS was performed by comparison with a standard curve of malondialdehyde (MDA) equivalents generated by acid-catalyzed hydrolysis of 1,1,3,3tetramethoxypropane. This curve was obtained in the same conditions as above using the phenol red-free Ham's F-10 in place of the oxidation mixture, and ranged from 0 to $8 \mu \mathrm{M}$.

\section{Cell viability test}

Cell viability was assessed by measuring lactate deshydrogenase (LDH) activity released by dead cells after cell incubation for $24 \mathrm{~h}$ with $\mathrm{FeSO}_{4}$, with or without LDL and with or without thyroid compounds. LDH activity was quantitated over time by spectrophotometric measurement of the production of $\mathrm{NADH}$ using a commercially available kit (LDH/LD, ref. 228-10; Sigma). At the end of each experiment, the culture medium was harvested and the cells were scraped and sonicated into PBS $(200 \mu \mathrm{l} /$ well). Extra- and intracellular LDH activities were measured in the culture medium and in the sonicated cell suspension respectively. Cell protein content was determined by the Lowry/Markwell procedure in the cell suspension.

Specific LDH activity (IU/g) was assessed by the ratio between LDH activity (IU/l) and medium protein concentration $(\mathrm{g} / \mathrm{l})$. Total specific LDH activity was obtained by adding intra- and extracellular specific activities. Relative intracellular LDH activity was obtained by the ratio between intracellular specific LDH activity and total specific LDH activity. The percentage of viability for one well was then represented by the ratio between its relative intracellular LDH activity and the relative LDH activity of cells in Ham's F-10 alone, considered as the 100\% viability.

\section{Statistics}

Results are presented as means \pm S.E.M. The levels of significance chosen were $P<0 \cdot 05$ and $P<0 \cdot 01$. Analysis of variance (ANOVA) was performed using the Systat program (Deltasoft, Meylan, France). Comparisons between variation percentages obtained in the presence of compounds and the $100 \%$ theoretical value of controls were done using the two-tailed Student's $t$-test.

\section{Results}

The effect of different concentrations of thyroid compounds on macrophage-induced LDL oxidation for $24 \mathrm{~h}$ is shown in Fig. 1. In the absence of cells, LDL peroxidation was negligible, whereas LDL produced about 30-35 nmol TBARS/mg protein in the presence of cells and $0.0025-$ $0 \cdot 05 \%$ of $\mathrm{NaOH}$ (thyroid compound diluent). At $0 \cdot 1 \%$ of $\mathrm{NaOH}$ corresponding to the $20 \mu \mathrm{M}$ concentration of thyroid compound, only $26 \mathrm{nmol}$ TBARS/mg LDL protein were produced, indicating that cell pro-oxidant activity was disturbed. This $20 \mu \mathrm{M}$ thyroid compound concentration was then omitted from further experiments. $\mathrm{T}_{0}$ had no effect on macrophage-induced LDL oxidation, whereas all the other compounds decreased it in a concentration-dependent manner. However, LDL TBARS production was strongly and similarly decreased by $\mathrm{T}_{4}$ and $\mathrm{rT}_{3}$, becoming negligible between 5 and $10 \mu \mathrm{M}$ 


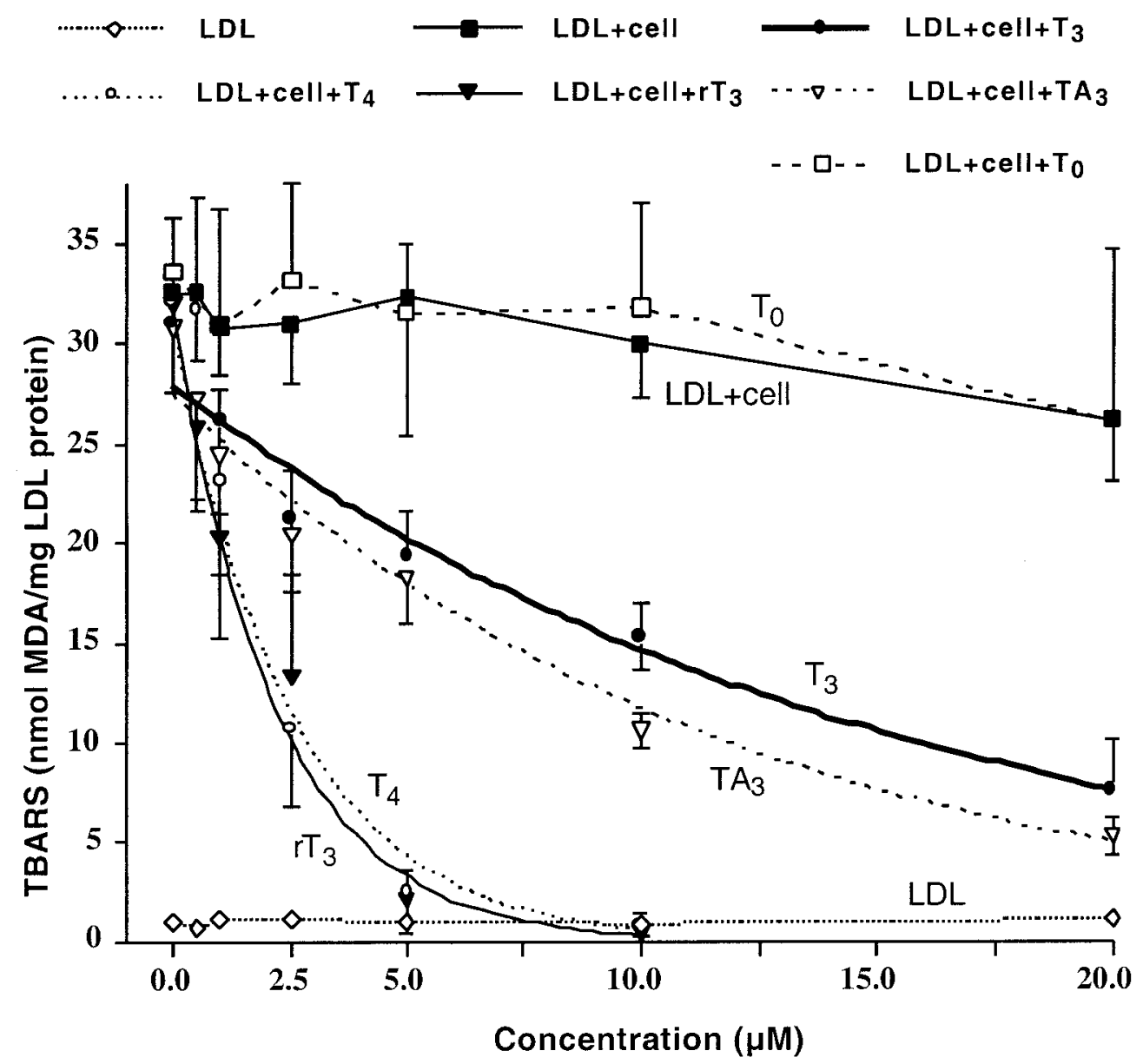

Figure 1 TBARS production by LDL alone (LDL), LDL in the presence of cells (LDL+cell) or LDL in the presence of cells and different concentrations of thyroid compounds (LDL+cell+compound) after $24 \mathrm{~h}$ of macrophage-induced LDL oxidation. Values are means \pm S.E.M. from four to six separate experiments performed in triplicate. In each experiment, each result was corrected by its control without LDL, then by its control without cells (except for LDL alone). For LDL and LDL+cell, the different values were obtained with thyroid compound diluent concentrations similar to those used in the presence of thyroid compounds, i.e. with $\mathrm{NaOH}$ concentrations ranging from $0.0025 \%$ to $0 \cdot 1 \%$ (see Materials and Methods for details).

of the compounds, whereas it was less decreased by $\mathrm{T}_{3}$ and $\mathrm{TA}_{3}$, reaching $5-7 \mathrm{nmol} / \mathrm{mg}$ protein at $20 \mu \mathrm{M}$. Compound concentrations which decreased TBARS production to $50 \%\left(\mathrm{IC}_{50}\right)$ are shown in Table $1 ; \mathrm{T}_{3}$ and $\mathrm{TA}_{3}$ had similar $\mathrm{IC}_{50}$ values of about $10 \mu \mathrm{M}$ whereas $\mathrm{T}_{4}$

Table 1 Thyroid compound concentrations $(\mu \mathrm{M})$ which decreased TBARS production to $50 \%\left(\mathrm{IC}_{50}\right)$ during $24 \mathrm{~h}$ macrophage-induced LDL oxidation. Values are means \pm S.E.M. from four to six data sets calculated from logarithmic regressions established in separate experiments performed in triplicate

$\begin{array}{llll}\mathbf{T}_{\mathbf{3}} & \frac{\mathbf{T}_{\mathbf{4}}}{11 \cdot 0 \pm 2 \cdot 6} & \frac{\mathbf{r}_{\mathbf{3}}}{0 \cdot 9 \pm 0 \cdot 5^{* *}} & \frac{\mathbf{T A}_{\mathbf{3}}}{8 \cdot 1 \pm 0 \cdot 8}\end{array}$

**P<0.01 compared with $T_{3}$ (Dunnett's test). and $\mathrm{rT}_{3}$ had an $\mathrm{IC}_{50}$ of about $1 \mu \mathrm{M}$. Thus, these two concentrations were used in further experiments.

The following results were obtained with macrophages preincubated or not with the thyroid compounds. When oxidation experiments were performed without LDL (Fig. 2 ), TBARS released in the incubation medium corresponded to the cell lipid peroxidation. When the cells were not preincubated, all the compounds at $10 \mu \mathrm{M}$ substantially decreased TBARS released by the cells. As expected, the decrease was less important with $1 \mu \mathrm{M}$ of the compound, except for $\mathrm{TA}_{3}$ which did not modify cell TBARS production. When the cells were preincubated with the compounds at $1 \mu \mathrm{M}$, TBARS release was not modified by any compound. However, at $10 \mu \mathrm{M}, \mathrm{T}_{3}$ and especially $\mathrm{T}_{4}$ protected macrophages from oxidation whereas $\mathrm{TA}_{3}$ increased cell oxidation, $\mathrm{rT}_{3}$ having no effect. 
$\begin{array}{lllllll} & \mathrm{T}_{3} \square & \mathrm{T}_{4} \square & \square & \mathrm{rT}_{3} & \square & \mathrm{TA}_{3}\end{array}$

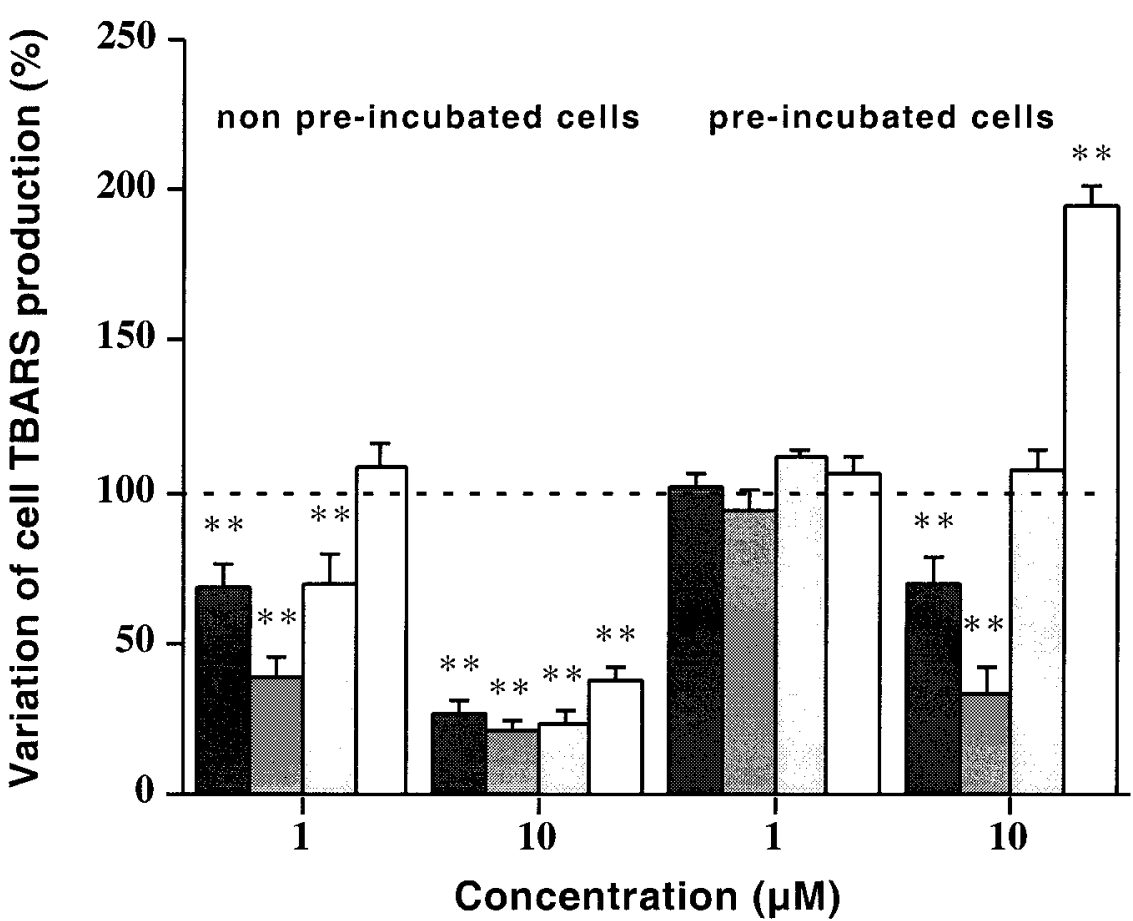

Figure 2 Variation percentages of cell TBARS production by macrophages preincubated or not in the presence of 1 or $10 \mu \mathrm{M}$ of different thyroid compounds during oxidation experiments without LDL. Values are means \pm S.E.M. from 15 data sets (five separate experiments performed in triplicate). ${ }^{*} P<0 \cdot 01$ compared with the control without thyroid compound (100\% TBARS production) (Student's $t$-test). Preincubated cells were incubated for $24 \mathrm{~h}$ with a thyroid compound, then washed and again incubated for $24 \mathrm{~h}$. Non-preincubated cells were incubated for $24 \mathrm{~h}$ without any compound, then washed and again incubated for $24 \mathrm{~h}$ with a thyroid compound (see Materials and Methods for details).

Variation of TBARS production by LDL oxidized by macrophages preincubated or not with the compounds at 1 or $10 \mu \mathrm{M}$ is presented in Fig. 3. In the non-preincubated cells, all the compounds inhibited LDL TBARS production, the inhibition being higher at $10 \mu \mathrm{M}$ than at $1 \mu \mathrm{M}$ and more important for $\mathrm{T}_{4}$ and $\mathrm{rT}_{3}$ than for $\mathrm{T}_{3}$ and $\mathrm{TA}_{3}$, confirming the previous results (Fig. 1). $\mathrm{T}_{3}$ was the less effective compound whatever the concentration. In the preincubated cells, $\mathrm{T}_{4}$ and $\mathrm{TA}_{3}$ reduced LDL TBARS production slightly at $1 \mu \mathrm{M}$ and by about $70 \%$ and $50 \%$ at $10 \mu \mathrm{M}$ respectively. $\mathrm{T}_{3}$ and $\mathrm{rT}_{3}$ had no effect at $1 \mu \mathrm{M}$ and decreased LDL TBARS only by about $10 \%$ at $10 \mu \mathrm{M}$.

Table 2 gives cell viability percentages assessed by LDH activity measurements during oxidation experiments with or without LDL. In the absence of thyroid compounds (control), cell viability in the presence of LDL was somewhat lower than that in the absence of LDL (one-way ANOVA, $P=0 \cdot 07)$, indicating that oxidized LDL were slightly toxic for macrophages. $\mathrm{T}_{3}, \mathrm{~T}_{4}$ or $\mathrm{rT}_{3}$ preincubated or not with macrophages did not change cell viability. On the contrary, $\mathrm{TA}_{3}$ lowered cell viability as compared with the control, especially at the $10 \mu \mathrm{M}$ concentration in macrophages preincubated or not with it, in the presence or in the absence of LDL (one-way ANOVA, $P<0 \cdot 01$ ).

\section{Discussion}

Culture of monocytic U937 cells and their differentiation into macrophages was performed in RPMI-1640 medium, whereas oxidation experiments were carried out in Ham's F-10 medium supplemented with $\mathrm{Fe}^{2+}$. Indeed, as reported by others, we have checked in preliminary studies that (1) very little if any macrophage LDL oxidation occurred in RPMI-1640 supplemented with up to $10 \mu \mathrm{M} \mathrm{Fe}^{2+}$ (Müller et al. 1998, Van Reyk et al. 1999), (2) iron was necessary to catalyze macrophage-mediated LDL oxidation (Müller et al. 1998, Yuan \& Brunk 1998), and (3) Ham's F-10 medium containing $3 \mu \mathrm{M} \mathrm{Fe}^{2+}$ ought to be supplemented with an additional $5 \mu \mathrm{M} \mathrm{Fe}^{2+}$ in order to 
$\begin{array}{lllllll}\mathrm{T}_{3} & \square & \mathrm{T}_{4} & \square & \mathrm{rT}_{3} & \square & \mathrm{TA}_{3}\end{array}$ non pre-incubated cells pre-incubated cells

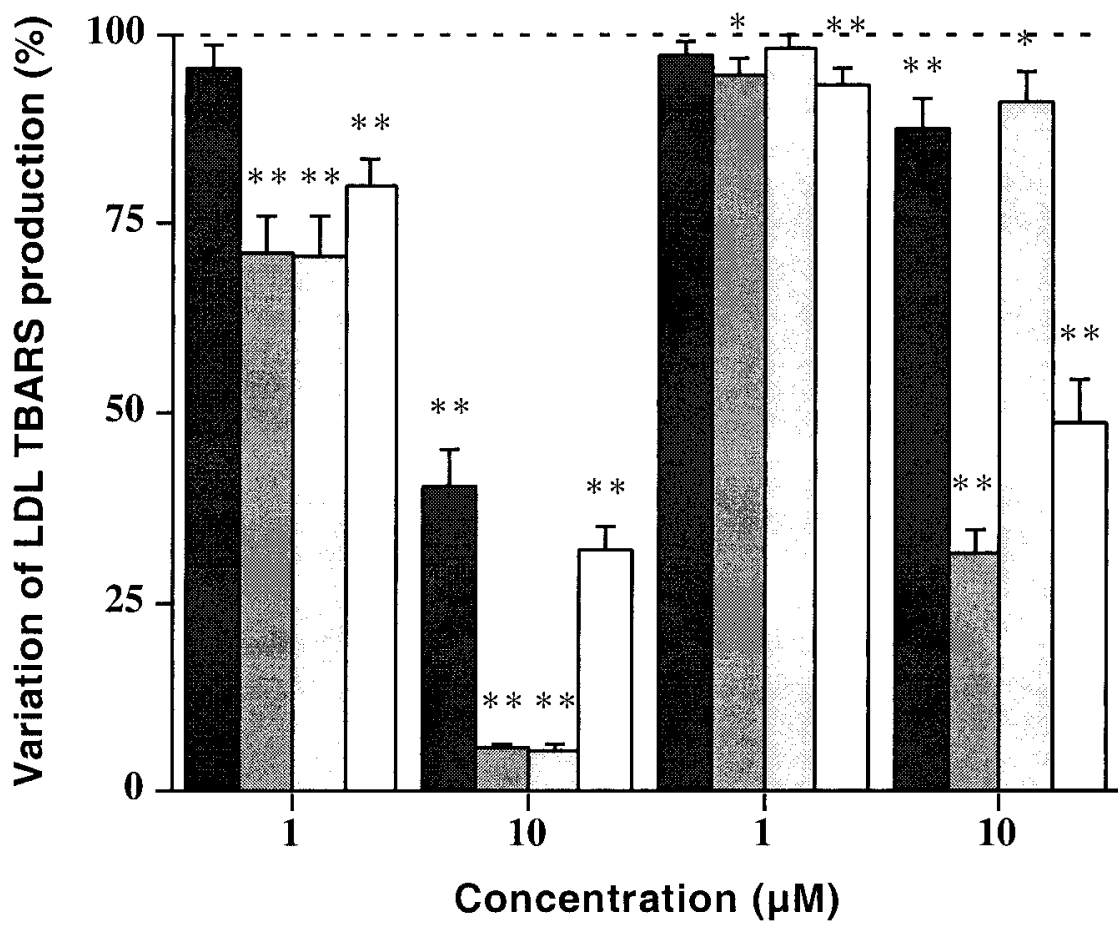

Figure 3 Variation percentages of LDL TBARS production by macrophages preincubated or not in the presence of 1 or $10 \mu \mathrm{M}$ of different thyroid compounds during oxidation experiments with LDL. Values are means \pm S.E.M. from 15 data sets (five separate experiments performed in triplicate). ${ }^{*} P<0 \cdot 05$ and ${ }^{* *} P<0 \cdot 01$ compared with the control without thyroid compound (100\% TBARS production) (Student's t-test). Preincubated cells were incubated for $24 \mathrm{~h}$ with a thyroid compound, then washed and again incubated for $24 \mathrm{~h}$. Non-preincubated cells were incubated for $24 \mathrm{~h}$ without any compound, then washed and again incubated for $24 \mathrm{~h}$ with a thyroid compound. In each experiment, each data set was corrected by its control without LDL (see Materials and Methods for details).

avoid limitation of LDL oxidation which may occur in some LDL preparations (Marchant et al. 1996). Note that this $\mathrm{Fe}^{2+}$ concentration induced neither LDL peroxidation in the absence of cells (Fig. 1) nor cell toxicity (Table 2), and that such iron concentrations have been reported in human atherosclerotic lesions (Yuan et al. 1996).

Thyroid hormones and structural analogues were reported to protect LDL from oxidation induced by non-cellular pro-oxidant agents (Hanna et al. 1993, Chomard et al. 1998, Oziol et al. 2001) and by endothelial cells (Hanna et al. 1995). In the present study, we found that these compounds also reduced macrophage-induced LDL oxidation in a concentration-dependent manner. Furthermore, they also protected macrophages themselves from lipid peroxidation. Such an observation was foreseeable since analogues of thyroid hormones with a $4^{\prime}$ hydroxy diphenylether structure have free radical scavenging capacity (Oziol et al. 2001) and since macrophages are able to generate ROS (Chisolm et al. 1999, Kaplan \& Aviram 1999) which may be captured by the thyroid compounds. The ability of thyroid compounds to decrease in vitro LDL oxidation induced by non-cellular prooxidant systems is a physico-chemical property of these compounds which may be effective whatever the prooxidant system.

However, $\mathrm{T}_{0}$, which has a great antioxidant effect on $\mathrm{Cu}^{2+}$ - or AAPH-induced LDL oxidation (Chomard et al. 1998, Oziol et al. 2001), was unable to protect LDL against macrophage-induced oxidation. This surprising observation led us to measure the antioxidant ability of the compounds in a classical in vitro LDL oxidation system, using Ham's F-10 medium as the working buffer. LDL were oxidized by $\mathrm{Cu}^{2+}$ or AAPH in the presence or not of thyroid compounds and conjugated dienes were continuously measured as previously described (Chomard et al. 1998). The results showed that Ham's F-10 itself protected 
Table 2 Viability (\%) of macrophages preincubated or not in the presence of 1 or $10 \mu \mathrm{M}$ of different thyroid compounds during oxidation experiments with or without LDL. Values are means \pm S.E.M. from four separate experiments performed in triplicate

\begin{tabular}{|c|c|c|c|c|c|c|}
\hline & & Control & $\mathbf{T}_{3}$ & $\mathbf{T}_{4}$ & $\mathrm{rT}_{3}$ & $\mathrm{TA}_{3}$ \\
\hline \multicolumn{7}{|l|}{ Without LDL } \\
\hline \multirow[t]{2}{*}{ Non-preincubated cells } & 1 & $102 \pm 3$ & $101 \pm 1$ & $103 \pm 2$ & $103 \pm 5$ & $100 \pm 2$ \\
\hline & 10 & $99 \pm 1$ & $105 \pm 2$ & $98 \pm 1$ & $106 \pm 3$ & $90 \pm 5$ \\
\hline \multirow[t]{2}{*}{ Preincubated cells } & 1 & $102 \pm 4$ & $104 \pm 4$ & $103 \pm 3$ & $104 \pm 3$ & $101 \pm 3$ \\
\hline & 10 & $102 \pm 1$ & $102 \pm 3$ & $97 \pm 1$ & $100 \pm 1$ & $91 \pm 6$ \\
\hline With LDL & $(\mu \mathrm{M})$ & & & & & \\
\hline \multirow[t]{2}{*}{ Non-preincubated cells } & 1 & $96 \pm 4$ & $100 \pm 2$ & $103 \pm 3$ & $104 \pm 3$ & $101 \pm 3$ \\
\hline & 10 & $98 \pm 4$ & $105 \pm 2$ & $101 \pm 2$ & $107 \pm 4$ & $96 \pm 3$ \\
\hline \multirow[t]{2}{*}{ Preincubated cells } & 1 & $98 \pm 4$ & $102 \pm 4$ & $102 \pm 4$ & $99 \pm 5$ & $100 \pm 4$ \\
\hline & 10 & $99 \pm 5$ & $102 \pm 3$ & $100 \pm 1$ & $100 \pm 3$ & $88 \pm 5$ \\
\hline
\end{tabular}

Preincubated cells were incubated for $24 \mathrm{~h}$ with a thyroid compound, then washed and again incubated for $24 \mathrm{~h}$.

Non-preincubated cells were incubated for $24 \mathrm{~h}$ without any compound, then washed and again incubated for $24 \mathrm{~h}$ with a thyroid compound. For control, the values were obtained with thyroid compound diluent concentrations similar to those used in the presence of thyroid compounds, i.e. with $0 \cdot 005 \%$ and $0.05 \% \mathrm{NaOH}$ (see Materials and Methods for details).

LDL against oxidation by the pro-oxidant agents, as compared with similar experiments performed in PBS, and that thyroid compounds had practically no additional antioxidant effects in the Ham's F-10 medium, particularly $\mathrm{T}_{0}$ (data not shown). The composition of Ham's F-10, rich in sulphured amino acids like cysteine or methionine and in vitamins like thiamine or pyridoxine, may well explain its antioxidant properties. In the present work using Ham's F-10 as oxidation medium, $\mathrm{T}_{0}$ was antioxidant inactive whereas other thyroid compounds were antioxidant active. It then appears that the physicochemical antioxidant property of thyroid compounds was not the major mechanism responsible for the protection of LDL against macrophage oxidation, at least in the extracellular medium.

Macrophages may oxidize extracellular LDL by releasing ROS generated via different enzymatic systems or derived from cell lipid peroxidation (Chisolm et al. 1999, Kaplan \& Aviram 1999). Transition metal ions like $\mathrm{Fe}^{2+}$ may favour macrophage ROS generation and LDL radical attack (Xing et al. 1998, Yuan \& Brunk 1998). If the radical scavenging capacity of thyroid compounds was predominant outside the cells, $\mathrm{T}_{3}$ and $\mathrm{TA}_{3}$ ought to have decreased LDL lipid peroxidation more than $\mathrm{T}_{4}$ and $\mathrm{rT}_{3}$, as previously found during AAPH-induced LDL oxidation (Oziol et al. 2001); however, we found the contrary here. Since $\mathrm{T}_{0}$ had no antioxidant effect here and considering the antioxidant capacity of Ham's F-10, as discussed above, it may be proposed that $\mathrm{T}_{0}$ does not enter the macrophages whereas the other compounds do, and/or that these compounds act on macrophage cellular mechanisms whereas $T_{0}$ does not. Consistent with this hypothesis is that $\mathrm{T}_{4}$ and $\mathrm{T}_{3}$, but not $\mathrm{T}_{0}$, inhibit lipid peroxidation in rat liver mitochondria (Cash et al. 1967); $\mathrm{T}_{0}$, which has no iodine, is less lipophilic than the iodo-thyroid compounds and probably cannot enter the cells by passive diffusion as do other iodothyronines (Hulbert 2000); finally, the iodo compounds are also able to enter cells by an energydependent transport system located in the plasma membrane (Kragie 1994, 1996) and are present in macrophages (Liu et al. 1989).

Thyroid compounds are able to act by several mechanisms inside the macrophage. As free radical scavengers (Oziol et al. 2001), they may reduce cellular flux of ROS, perhaps degrading themselves by ether-link cleavage. Indeed, this is a thyroid hormone oxidation process, frequently observed during in vitro experiments using macrophages and which needs $\mathrm{H}_{2} \mathrm{O}_{2}$ (Green 1994). This process would be (1) a major pathway of thyroid hormone degradation into human phagocytes, (2) favoured by different proteins with peroxidase activity like myeloperoxidase, and (3) active on $\mathrm{T}_{4}$ as well as on $\mathrm{T}_{3}$ (Klebanoff \& Green 1973, Burger et al. 1983, Meinhold \& Buchholz 1986). Thus ether-link cleavage of iodothyronines could consume $\mathrm{H}_{2} \mathrm{O}_{2}$ and reduce the activity of macrophage myeloperoxidase which is involved in LDL Apolipoprotein B100 and lipid oxidation (Carr et al. 2000). Thyroid compounds may also chelate cell transition metals. Indeed, $\mathrm{T}_{3}$ and $\mathrm{TA}_{3}$ have been shown to disturb LDL $\mathrm{Cu}^{2+}$ binding suggesting that they have chelating properties for this metal (Faure et al. 1999).

Free radical scavenging or transition metal chelation do not completely explain our results, particularly when macrophages were preincubated with the thyroid compounds, then rinsed, then incubated again with native LDL. First, $T_{3}$ and $\mathrm{TA}_{3}$ reduced, more severely than $\mathrm{T}_{4}$ and $\mathrm{rT}_{3}$, LDL oxidation induced by $\mathrm{Cu}^{2+}$ (Chomard et al. 1998) or AAPH (Oziol et al. 2001), whereas we found the contrary here in the non-preincubated macrophages. Secondly, in the preincubated macrophages, $\mathrm{T}_{4}$ protected 
the cells (Fig. 2) and the LDL (Fig. 3) from oxidation, much more than $T_{3}$. We can then assume that thyroid compounds act partly on different systems responsible for the oxidative status of cells.

High affinity $T_{3}$ and $T_{4}$ receptors exist in human mononuclear cells (Burman et al. 1980) and thyroid hormones are known to regulate redox enzyme activities. During hyperthyroidism, NAD $(\mathrm{P}) \mathrm{H}$ oxidase activity was increased in rat (Fernandez \& Videla 1995) and human (Magsino et al. 2000) leukocytes or human phagocytes (Videla et al. 1993); this was also true for $\mathrm{Cu} / \mathrm{Zn}$ - and Mn-superoxide dismutase (SOD) in rat leukocytes (Pereira et al. 1994). In hypothyroid rat macrophages, $\mathrm{Mn}-\mathrm{SOD}$, catalase and glutathion peroxidase (GPx) activities were decreased; thyroid hormones added to cultured rat macrophages increased SOD activities, leading to a decrease in cell $\mathrm{H}_{2} \mathrm{O}_{2}$ production and GPx activity (Pereira et al. 1995). Myeloperoxidase was stimulated by $\mathrm{T}_{3}$ and $\mathrm{T}_{4}$ in isolated human leukocytes (Van Zyl et al. 1989). Thus, thyroid compounds are susceptible to induce modifications in the macrophage oxidant/ antioxidant status, the result of which determines their overall cellular redox effect. In the preincubated cells, the modifications of lipid peroxidation may be partly due to the effect of thyroid compounds on pro- or antioxidant enzyme expression, whereas in the non-preincubated cells, physico-chemical antioxidant properties of the compounds may be modulated by this probably transcriptional effect. This hypothesis is supported by the fact that $\mathrm{rT}_{3}$, which has no affinity for thyroid hormone receptors (Jorgensen 1981), had practically no more activity in the preincubated cells, either on lipid peroxidation of macrophages (Fig. 2) or on that of LDL (Fig. 3).

Surprisingly, $\mathrm{TA}_{3}$ protected LDL from oxidation in the non-preincubated cells as $T_{3}$ did (Figs 1 and 3), whereas $\mathrm{TA}_{3}$ was more effective than $\mathrm{T}_{3}$ in the preincubated cells (Fig. 3). It may be suspected that $\mathrm{TA}_{3}$, which has a higher thyroid hormone receptor affinity than $\mathrm{T}_{3}$ (Takeda et al. 1995), behaves differently from $T_{3}$ on the redox systems. However, $\mathrm{TA}_{3}$ slightly decreased macrophage viability whereas the other compounds did not (Table 2). It also protected cells from peroxidation less than the other compounds, particularly at $10 \mu \mathrm{M}$ in the preincubated cells where it increased TBARS production (Fig. 2). As a result, the rather significant inhibition of LDL lipid peroxidation by $\mathrm{TA}_{3}$ (Fig. 3) may be explained, at least in part, by (1) a partial destruction of cells which reduce their pro-oxidant capabilities (Marchant et al. 1996, Müller et al. 1998), and (2) an artefact due to the calculation of this inhibition, i.e. subtraction of TBARS due to cell lipid peroxidation from those due to cell and LDL lipid peroxidation. Indeed, TBARS from cells being high with $\mathrm{TA}_{3}$ (at $10 \mu \mathrm{M}: 9 \cdot 4 \mathrm{nmol}$ versus less than $5.4 \mathrm{nmol}$ in all other cases), their subtraction from cell and LDL TBARS undervalued LDL TBARS production, leading to an underestimation of the variation percentage.
Finally, thyroid compounds might act as antioxidants in cell membranes (Hulbert 2000). In the rat, $\mathrm{T}_{4}$ content of different tissues is proportional to the phospholipid content of these tissues. Thyroid hormones rigidify membranes with which they combine, reducing their fluidity; it is a very fast phenomenon, independent of the classical action of hormones, and $\mathrm{T}_{3}$ and $\mathrm{T}_{4}$ may have different effects. The direct antioxidant role of thyroid compounds inside biological membranes remains to be proved. It should, however, be taken into account for the interpretation of our results concerning $\mathrm{rT}_{3}$. Indeed, this compound revealed a great antioxidant effect against macrophageinduced LDL oxidation in the non-preincubated cells, as high as that of $\mathrm{T}_{4}$ (Figs 1 and 3), whereas it is thyromimetic inactive and was as antioxidant as $\mathrm{T}_{4}$, and less antioxidant than $\mathrm{T}_{3}$ during LDL oxidation by non-cellular pro-oxidant agents (Chomard et al. 1998, Oziol et al. 2001). Note that $\mathrm{rT}_{3}$, like $\mathrm{T}_{4}$, possesses two iodine atoms in the $3^{\prime}$ and $5^{\prime}$ position which influence their lipophilicity (Hulbert 2000), whereas $\mathrm{T}_{3}$ and $\mathrm{TA}_{3}$ have only one iodine atom at $3^{\prime}$. The fact that $\mathrm{rT}_{3}$ has a priori no effect on thyroid hormone receptors cannot explain by itself its great antioxidant effect here, as compared with $\mathrm{T}_{4}$.

In conclusion, during macrophage-induced LDL oxidation, the thyroid compounds probably act by different mechanisms which explains the differences observed between them. They have physico-chemical antioxidant effects which was demonstrated in $\mathrm{Cu}^{2+}$ - and AAPHinduced LDL oxidation in vitro (Hanna et al. 1993, Chomard et al. 1998, Oziol et al. 2001), and cellular effects due to their binding on the thyroid hormone receptors and probably to other non-transcriptional effects. The more significant result of our work is that overall cellular effects of $\mathrm{T}_{3}$ led to a reduction of its antioxidant capacity, whereas those of $\mathrm{T}_{4}$ induced an increase in its ability to reduce macrophage-induced LDL oxidation. Thus $\mathrm{T}_{4}$ might have a protective effect against cellular-induced LDL oxidation in vivo. This hypothesis is consistent with the fact that LDL are more oxidizable and more oxidized in hypothyroid than in euthyroid subjects, perturbations which are restored by a $\mathrm{T}_{4}$ treatment (Sundaram et al. 1997, Diekman et al. 1998).

\section{Acknowledgements}

The U937 human monocyte-like cell line (ATCC) was a gift from INSERM U517, Dijon, France.

\section{References}

Bianchi G, Solaroli E, Accheroni V, Grossi G, Bargossi AM, Melchionda N \& Marchesini G 1999 Oxidative stress and anti-oxidant metabolites in patients with hyperthyroidism: effect of treatment. Hormone and Metabolic Research 31 620-624. 
Burger AG, Engler D, Buergi U, Weissel M, Steiger G, Ingbar SH, Rosin RE \& Babior BM 1983 Ether link cleavage is the major pathway of iodothyronine metabolism in the phagocytosing human leukocyte and also occurs in vivo in the rat. Journal of Clinical Investigation 71 935-949.

Burman KD, Latham KR, Djuh YY, Smallridge RC, Tseng YC, Lukes YG, Maunder R \& Wartofsky L 1980 Solubilized nuclear thyroid hormone receptors in circulating human mononuclear cells. Journal of Clinical Endocrinology and Metabolism 51 106-116.

Carr AC, McCall MR \& Frei B 2000 Oxidation of LDL by myeloperoxidase and reactive nitrogen species: reaction pathways and antioxidant protection. Arteriosclerosis Thrombosis and Vascular Biology 20 1716-1723.

Cash WD, Carlson HE, Cox SW, Ekong EA, Epstein JS \& Sigel RM 1967 Studies on the antioxidant action of thyroxine and related compounds. Journal of Medicinal Chemistry 10 1081-1085.

Chisolm GM \& Steinberg D 2000 The oxidative modification hypothesis of atherogenesis: an overview. Free Radical Biology and Medicine 28 1815-1826.

Chisolm GM, Hazen SL, Fox PL \& Cathcart MK 1999 The oxidation of lipoproteins by monocytes-macrophages. Journal of Biological Chemistry $27425959-25962$.

Chomard P, Seguin C, Loireau A, Autissier N \& Artur Y 1998 Effects of iodotyrosines, thyronines, iodothyroacetic acids and thyromimetic analogues on in vitro copper-induced oxidation of low-density lipoproteins. Biochemical Pharmacology 55 1591-1601.

Costantini F, Pierdomenico SD, De Cesare D, De Remigis P, Bucciarelli T, Bittolo Bon G, Cazzolato G, Nubile G, Guagnano MT, Sensi S, Cuccurullo F \& Mezzetti A 1998 Effect of thyroid function on LDL oxidation. Arteriosclerosis Thrombosis and Vascular Biology 18 732-737.

Danese MD, Ladenson PW, Meinert CL \& Powe NR 2000 Effect of thyroxine therapy on serum lipoproteins in patients with mild thyroid failure: a quantitative review of the literature. Journal of Clinical Endocrinology and Metabolism 85 2993-3001.

Diekman T, Demacker PNM, Kastelein JJP, Stalenhoef AFH \& Wiersinga WM 1998 Increased oxidizability of low-density lipoproteins in hypothyroidism. Journal of Clinical Endocrinology and Metabolism 83 1752-1755.

Faure P, Oziol L, Artur Y \& Chomard P 1999 Triiodothyronine $\left(T_{3}\right)$ and its acetic derivative $\left(\mathrm{TA}_{3}\right)$ reduced in vitro copper-induced $\mathrm{LDL}$ oxidation by different mechanisms. Chemistry and Physics of Lipids 101167 (Symposium topic/number T3/P1).

Fernandez V \& Videla LA 1995 On the mechanism of thyroid hormone-induced respiratory burst activity in rat polymorphonuclear leukocytes. Free Radical Biology and Medicine 19 359-363.

Fuhrman B, Oiknine J \& Aviram M 1994 Iron induces lipid peroxidation in cultured macrophages, increases their ability to oxidatively modify LDL, and affects their secretory properties. Atherosclerosis 111 65-78.

Green WL 1994 Ether-link cleavage of iodothyronines. In Thyroid Hormone Metabolism. Molecular Biology and Alternate Pathways, pp 199-221. Eds SY Wu \& TJ Visser. Boca Raton: CRC Press Inc.

Hanna AN, Feller DR, Witiak DT \& Newman HAI 1993 Inhibition of low density lipoprotein oxidation by thyronines and probucol. Biochemical Pharmacology 45 753-762.

Hanna AN, Titterington LC, Lantry LE, Stephens RE \& Newman HAI 1995 Thyronines and probucol inhibition of human capillary endothelial cell-induced low density lipoprotein oxidation. Biochemical Pharmacology 50 1627-1633.

Hulbert AJ 2000 Thyroid hormones and their effects: a new perspective. Biological Reviews of the Cambridge Philosophical Society $\mathbf{7 5}$ 519-631.

Jorgensen EC 1981 Thyromimetic and antithyroid drugs. In Burger's Medicinal Chemistry, edn 4, part 3, pp 103-145. Ed. ME Wolff. New York: John Wiley \& Sons.
Kaplan M \& Aviram M 1999 Oxidized low density lipoprotein: atherogenic and proinflammatory characteristics during macrophage foam cell formation. An inhibitory role for nutritional antioxidants and serum paraoxonase. Clinical Chemistry and Laboratory Medicine $\mathbf{3 7}$ 777-787.

Klebanoff SJ \& Green WL 1973 Degradation of thyroid hormones by phagocytosing human leukocytes. Journal of Clinical Investigation $\mathbf{5 2}$ 60-72.

Kleinveld HA, Hak-Lemmers HLM, Stalenhoef AFH \& Demacker PNM 1992 Improved measurement of low-density-lipoprotein susceptibility to copper-induced oxidation: application of a short procedure for isolating low-density lipoprotein. Clinical Chemistry 38 2066-2072.

Kragie L 1994 Membrane iodothyronine transporters part 1: review of physiology. Endocrine Research 20 319-341.

Kragie L 1996 Membrane iodothyronine transporters part 2: review of protein biochemistry. Endocrine Research 22 95-119.

Lamb DJ, Mitchinson MJ \& Leake DS 1995 Transition metal ions within human atherosclerotic lesions can catalyse the oxidation of low density lipoprotein by macrophages. FEBS Letters 374 12-16.

Liu WK, Wong CC \& Mak NK 1989 Localization of thyroid hormone in subpopulations of rat alveolar macrophages. Histochemical Journal 21 115-121.

Magsino CH Jr, Hamouda W, Ghanim H, Browne R, Aljada A \& Dandona P 2000 Effect of triiodothyronine on reactive oxygen species generation by leukocytes, indices of oxidative damage and antioxidant reserve. Metabolism 49 799-803.

Marchant CE, Van Der Veen C, Law NS, Hardwick SJ, Carpenter KLH \& Mitchinson MJ 1996 Oxidation of low-density lipoprotein by human monocyte-macrophages results in toxicity to the oxidising culture. Free Radical Research 24 333-342.

Markwell MAK, Haas SM, Buber LL \& Tolbert NE 1978 A modification of the Lowry procedure to simplify protein determination in membrane and lipoprotein samples. Analytical Biochemistry 87 206-210.

Martinez Triguero ML, Hernandez Mijares A, Nguyen TT, Munoz ML, Pena H, Morillas C, Lorente D, Lluch I \& Molina E 1998 Effect of thyroid hormone replacement on lipoprotein(a), lipids, and apolipoproteins in subjects with hypothyroidism. Mayo Clinic Proceedings 73 837-841.

Meinhold H \& Buchholz R 1986 In vivo formation of diiodotyrosine by extrathyroidal thyroxine ether-link cleavage and effects of mononitrotyrosine on this pathway in the rat. Endocrinology 118 2305-2311.

Müller K, Carpenter KLH \& Mitchinson MJ 1998 Cell-mediated oxidation of LDL: comparison of different cell types of the atherosclerotic lesion. Free Radical Research 29 207-220.

O’Brien T, Katz K, Hodge D, Nguyen T, Kottke BA \& Hay ID 1997 The effect of the treatment of hypothyroidism and hyperthyroidism on plasma lipids and apolipoproteins AI, AII and E. Clinical Endocrinology 46 17-20.

Oziol L, Faure P, Vergely C, Rochette L, Artur Y \& Chomard P 2001 In vitro free radical scavenging capacity of thyroid hormones and structural analogues. Journal of Endocrinology 170 197-206.

Pereira B, Rosa LF, Safi DA, Bechara EJ \& Curi R 1994 Control of superoxide dismutase, catalase and glutathione peroxidase activities in rat lymphoid organs by thyroid hormones. Journal of Endocrinology $14073-77$.

Pereira B, Rosa LF, Safi DA, Bechara EJ \& Curi R 1995 Hormonal regulation of superoxide dismutase, catalase and glutathione peroxidase activities in rat macrophages. Biochemical Pharmacology $\mathbf{5 0}$ 2093-2098.

Sundaram V, Hanna AN, Koneru L, Newman HAI \& Falko JM 1997 Both hypothyroidism and hyperthyroidism enhance low density lipoprotein oxidation. Journal of Clinical Endocrinology and Metabolism 82 3421-3424. 
Takeda T, Suzuki S, Liu RT \& DeGroot LJ 1995 Triiodothyroacetic acid has unique potential for therapy of resistance to thyroid hormone. Journal of Clinical Endocrinology and Metabolism $\mathbf{8 0}$ 2033-2040.

Van Reyk DM, Jessup W \& Dean RT 1999 Prooxidant and antioxidant activities of macrophages in metal-mediated LDL oxidation: the importance of metal sequestration. Arteriosclerosis Thrombosis and Vascular Biology 19 1119-1124.

Van Zyl JM, Basson K \& Van der Walt BJ 1989 Stimulation of the chlorinating activity of human myeloperoxidase by thyroid hormones and analogues. Hormone and Metabolic Research 21 441-444.

Videla LA, Correa L, Rivera M \& Sir T 1993 Zymosan-induced luminol-amplified chemiluminescence of whole blood phagocytes in experimental and human hyperthyroidism. Free Radical Biology and Medicine 14 669-675.
Witztum JL \& Steinberg D 2001 The oxidative modification hypothesis of atherosclerosis; does it hold for humans? Trends in Cardiovascular Medicine 11 93-102.

Xing X, Baffic J \& Sparrow CP 1998 LDL oxidation by activated monocytes: characterization of the oxidized LDL and requirement for transition metal ions. Journal of Lipid Research 39 2201-2208.

Yuan XM \& Brunk UT 1998 Iron and LDL-oxidation in atherogenesis. Acta Pathologica, Microbiologica et Immunologica Scandinavica 106 825-842.

Yuan XM, Anders WL, Olsson AG \& Brunk UT 1996 Iron in human atheroma and LDL oxidation by macrophages following erythrophagocytosis. Atherosclerosis 124 61-73.

Received 16 December 2002

Accepted 15 January 2003 